\title{
Evidence for the Upwelling of Mafic Bodies into the Upper Crust beneath the N40-50 E Branch of the Pan-African Central Cameroon Shear Zone from Gravity Studies
}

\author{
Loudi Yap1,2*, Robert Nouayou1, Depesquidoux Tchaptchet Tchato ${ }^{3}$, Joseph Kamguia1,2 \\ Apollinaire Bouba1,4 \\ ${ }^{1}$ Department of Physics, Faculty of Sciences, University of Yaoundé 1, Yaoundé, Cameroon \\ ${ }^{2}$ Research Laboratory in Geodesy, National Institute of Cartography, Yaoundé, Cameroon \\ ${ }^{3}$ Department of Earth Sciences, Faculty of Sciences, University of Yaoundé 1, Yaoundé, Cameroon \\ ${ }^{4}$ Department of Physics, Advanced Teacher's Training College, University of Maroua, Maroua, Cameroon \\ Email: *loudiyap@yahoo.fr
}

How to cite this paper: Yap, L., Nouayou, R., Tchaptchet Tchato, D., Kamguia, J. and Bouba, A. (2018) Evidence for the Upwelling of Mafic Bodies into the Upper Crust beneath the $\mathrm{N} 40-50^{\circ} \mathrm{E}$ Branch of the Pan-African Central Cameroon Shear Zone from Gravity Studies. Open Journal of Geology, 8, 278-297.

https://doi.org/10.4236/ojg.2018.83018

Received: May 31, 2017

Accepted: March 24, 2018

Published: March 27, 2018

Copyright $\odot 2018$ by authors and Scientific Research Publishing Inc. This work is licensed under the Creative Commons Attribution International License (CC BY 4.0).

http://creativecommons.org/licenses/by/4.0/

\begin{abstract}
The existence of mafic bodies at mid crustal level beneath the Pan-African Central Cameroon Shear Zone is still a matter of debate. To provide additional constrains on this issue, the crust of the west region of Cameroon has been investigated using gravity data. Analyses of these data show $\mathrm{N} 40-50^{\circ} \mathrm{E}$ oriented iso-anomal contours in the Bafoussam area, interpreted as the N40-50 ${ }^{\circ} \mathrm{E}$ branch of the Central Cameroon Shear Zone. In addition, spectral analysis and $2.5 \mathrm{D}$ gravity modeling reveal intrusions of mafic bodies at depth between 3.2 and $14.2 \mathrm{~km}$ under N40-50 $\mathrm{E}$ aligned volcanic centers, namely Mt Bambouto and Mt Mbapit. The above observations suggest a structurally controlled emplacement of the mafic bodies. In the light of the recent geophysical data, the interaction between the NE-ward channel flow operating at the bottom of the lithosphere or the asthenosphere upwelling and the Cameroon Shear Zone could better explain the magma upwelling in the upper crust. This result is the novelty of the present work.
\end{abstract}

\section{Keywords}

West Region, Mafic Bodies, Central Cameroon Shear Zone, Gravity, 2.5D Modelling

\section{Introduction}

The crust at the northern margin of the Congo Craton overprinted by a network 
of Pan-African shear zone (Figure 1(a)) has beneficiated from many geophysical studies [1]-[10] which have improved our knowledge about the crustal structure and even mantle beneath the Cameroon territory.

However, there is no consensus on the upper crustal structure, especially about the existence of intrusions at mid-crustal level. Some authors [5] [6] [7] [8] [9] [11] forwarded that there is heterogeneity at mid crustal levels made by upwelling of magmatic body beneath the central Cameroon domain. Others [4] [13] [14] [15], rather stated that there is no mafic intrusion because the crustal was not significantly modified. In order to provide constrain on this issue, the west Region of Cameroon which contains not only the N40-50 $\mathrm{E}$ branch of Central

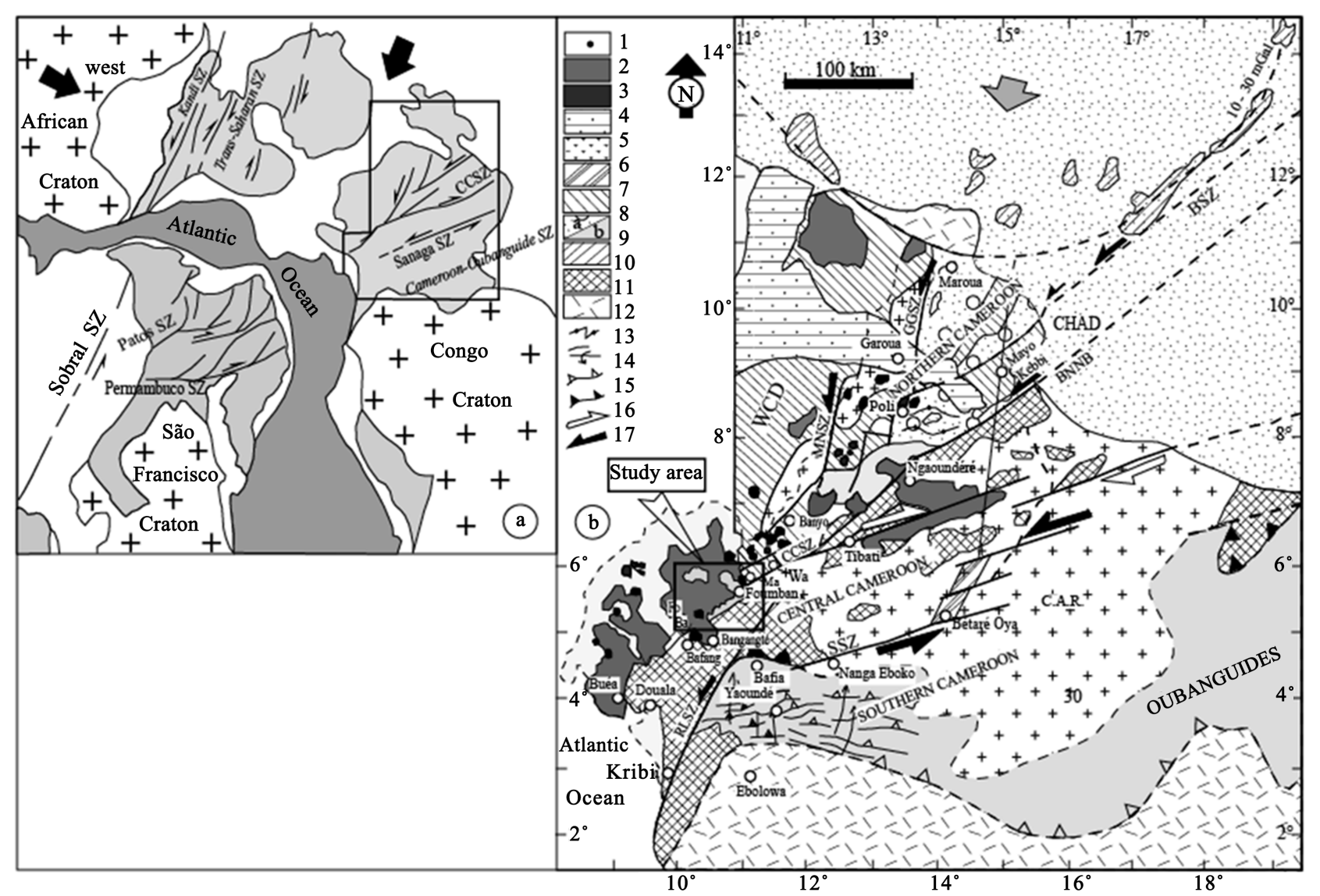

Figure 1. (a) Pan-African shear zone network in pre-Mesozoic reconstruction (after Caby 1989. modified). SZ = Shear Zone: C = Cameroon area; (b) Pan-African structural map of Cameroon and localization of the study area (modified from [12]). 1: Quaternary sediments; 2: Cameroon Line Volcanism; 3: Cameroon Line plutonism; 4: Mesozoic sediments (Benue through); 5: Late syntectonicsubalkalinegranitoids; 6: Lom syntectonic basin (meta-sediments, conglomerates, volcanic ashes and lavas); 7: Western Cameroon Domain (WCD: early syntectonic basic to intermediate calc-alkaline intrusions, 660 - 600 Ma); 8a: Poli Group (active margin Neoproterozoic supracrustal and juvenile intrusions) 8b: Yaounde Group (intracratonic deposits); 9: Massenya-Ounianga gravity highs (10 - $30 \mathrm{mGal}) ; 10$ : Adamawa-Yadé and Nyong Paleoproterozoic remnants; 11: Craton and inferred craton; 12: $\mathrm{S}_{2}$ foliation and $\mathrm{L}_{2}$ lineation trends; $13: \mathrm{F}_{2}$ upright and overturned antiforms; 14: syn- $\mathrm{D}_{2}$ main frontal thrust zone; 15: syn- $\mathrm{D}_{1}$ thrust zone (separates the LP to MP zone in the North from the HP zone in South); 16: Syn- $\mathrm{D}_{3}$ sense of shear movement; 17:Syn- $\mathrm{D}_{2}$ sense of shear movement. Large grey arrow represents Syn- $D_{1-3}$ regional main stress direction. Thick lines = shear zones $(S Z)$ : BSZ = Balché SZ; BNMB = Buffle Noir-Mayo Baléo SZ; CCSZ = Cameroon Central SZ; GGSZ = Godé-Gormaya SZ; MNSZ = Mayo Nolti SZ; RLSZ = Rocher du Loup SZ; SSZ = Sanaga SZ; Ma = Magha; Wa = Wakaa. Small squares: Ba = Bandja complex; Fo = Fomopéa complex. 
Cameroon Shear Zone (CCSZ) but also flood basalts, volcanic centers and volcanic lakes, whose alignment coincides with the orientation of that branch, makes it a key area to be investigated. Moreover, no detailed geophysical studies were done in the area and constitute an excellent area to assess the relationship between the upwelling of mafic intrusion and the Pan-African CCSZ. To improve our knowledge about the aforementioned issue, the geophysical study using gravity data aims to 1) identify the major density discontinuities in the upper crust from spectral analysis; 2 ) constrain the $2.5 \mathrm{D}$ gravity modelling of the upper crustal structure in the area; 3 ) correlate the results obtained, to those reported in $\mathrm{N} 60-70^{\circ} \mathrm{E}$ branch exposed in the Adamawa plateau. These will be used to identify the implication of CCSZ in the upwelling of mafic body into the upper crust.

\section{Geological Setting}

The study area belongs to the Adamawa-Yadé domain [12] of the Central African Fold Belt in Cameroon (Figure 1(b)). It is made up of (Figure 2) an assemblage of high grade gneiss 1) $2100 \mathrm{Ma}$ old Paleoproterozoic granulites-facies rocks occuring in Kekem [12], Tonga [16] and the area of Bafia [17], 2) Neoproterozoic metasedimentary rocks [18] [19] which contains amphibolites xenoliths. These gneisses are affected by NE striking ductile transcurrent/transpression shear zone known as Foumban-Foutoni shear zone [20] [21] [22] [23] which has controlled the emplacement of 610 to $570 \mathrm{Ma}$ post-collision granitoids (leucogranites, granites, syenites) of high-K calc-alkaline, peraluminous and shoshonitic affinities [21] [24] [25].

These basement rocks are cross cut by $420 \mathrm{Ma}$ Paleozoic sub-alkaline tholeiites basalt dyke swarms [27] [28] in the area of Dschang, Baham and Bafoussam. They are considered as within-plate magmatism developed in rift setting in relation with the opening of the South Atlantic Ocean [28]. The above mentioned rocks are associated with Cenozoic to Recent magmatic rocks. The latter consists of anorogenic complexes (e.g.: Nda Ali massif; Nkogam massif ) and centers such as Mt Bambouto, Mt Mbapit [29], Mt Bana [30], Mt Bangou [31] and flood basalts. This displays a various chemical affinities which include alkaline [32]; transitional [31] and tholeiitic [30].

\section{Data Sources and Methods}

\subsection{The Origin of Gravity Data}

The gravity data used in this study were collected during several surveys carried out in Cameroon by IRD (Institut de Recherche pour le Développement, France) between 1963 and 1968 [33] and released by the Bureau Gravimétrique International (BGI). The data was collected at $4 \mathrm{~km}$ mean intervals at all gravity stations including base stations, on all available roads and tracks in the area, using Worden and Lacoste \& Romberg gravimeters with a mean resolution of $0.01 \mathrm{mGal}$ [34]. The estimated accuracy for the gravity measurement is about $0.2 \mathrm{mGal}$ 


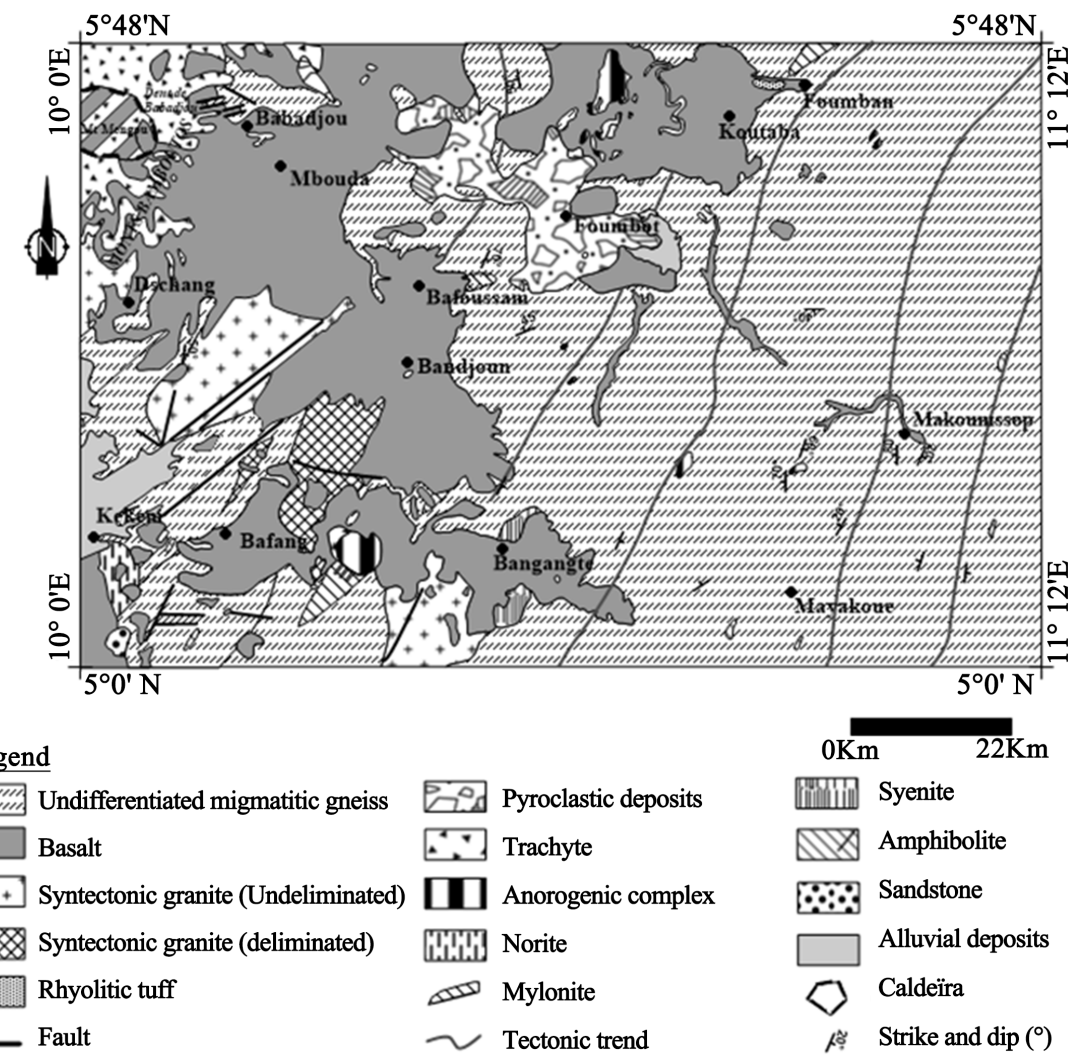

- Locality

Figure 2. Geological map of the studied area (after [26], modified).

[35]. All gravity measurements are tied to the International Gravity Standardization Network 1971 (IGSN71) datum after correction of luni-solar effect and instrumental drift. To determine the free air anomaly, the linear vertical gradient of $0.3086 \mathrm{mGal} / \mathrm{m}$ was used to approximate free air correction. In order to take care of the gravitational effect of the horizontal infinite slab of rock between the gravity station and the datum, the Bouguer correction is applied with a density reduction of $2.67 \mathrm{~g} \cdot \mathrm{cm}^{-3}$. Due to the presence of relatively smooth topography, no terrain correction was added. Indeed, care is taken to avoid sitting gravity stations in the vicinity of local and very important topographic features, and is on a regional scale on the same average level topography [34] [36]. The Bouguer anomaly map of the area is obtained after interpolation, using the continuous curvature gridding algorithm and contoured in the Generic Mapping Tools (GMT) software [37].

\subsection{Method for Estimating the Optimum Upward-Continuation Height for Gravity Separation}

The Bouguer gravity anomalies include the effect of deep and shallow sources reflecting the lateral inhomogeneities in each. In order to enhance the signatures of mafic materials into the upper crust, observed data are separated into regional and residual anomalies [38] using polynomial fitting based on the least-squares method. In order to choose the order of the regional field which fixes the resi- 
dual one, this method which is the most flexible and efficient analytical technique [39] [40] is combined with optimum upward continuation method [38] to determine the best surface representing regional field. The selection criterion of the regional field is the more objective, as it is based on the correlation between the regional analytical and the regional spectral. This correlation also determines the depth of investigation and takes into account the variations of Bouguer anomalies in all the directions [41] [42]. Indeed, to derive an optimum upward continuation height $h_{0}$ for gravity separation, the empirical method of [41] was used.

The upward continuation is a method used to separate a regional gravity anomaly resulting from deep sources from the observed gravity [41]. The optimum upward continuation height is obtained by the maximum cross correlation between the upward continued fields at the successive heights which presents a maximum deflection. More details concerning the steps of data treatment are found in [41] [42] [43] and references therein.

\subsection{Estimation Method of the Investigation Depth}

The investigation depth is the maximum depth of the sources whose anomalies constitute the residual field. This depth is fixed by optimum upward continuation height $\mathrm{h}_{0}$. Indeed, on the basis of a model of basement made up of an assembly of thin layers, [44] showed that the power spectrum of regional and residual fields can be expressed in the form of:

$$
\begin{gathered}
P_{\text {reg }}(k)=c \cdot \frac{s(k)}{2 k \Delta z} \mathrm{e}^{-2 k z_{0}} \\
P_{\text {res }}(k)=c \cdot \frac{s(k)}{2 k \Delta z}\left(1-\mathrm{e}^{-2 k z_{0}}\right)
\end{gathered}
$$

where $s(k)$ is the power spectrum of a density distribution of a thin layer; $k$ is the radial wave number $\left(k=\sqrt{k_{x}^{2}+k_{y}^{2}}\right) ; \Delta z$ is the vertical space between the thin layers.

The residual field is caused by the thin layer situated above the depth $h_{0}$ and the regional field is caused by the thin layers situated below the depth $h_{0}$. The power spectrum of the total field is given by:

$$
P(k)=P_{\text {reg }}(k)+P_{\text {res }}(k)=C \cdot \frac{s(k)}{2 k \Delta z}
$$

when $P(k)$ is multiplied by the filter $F(k)=\mathrm{e}^{-2 k z_{0}}$ we obtain $P_{\text {reg }}(k)$. In the Fourier domain, $F(k)=\mathrm{e}^{-2 k z_{0}}$ is the operator which, applied to the Bouguer anomaly, permits the extraction of the regional anomaly. Its expression shows that it also corresponds to the filter of the upward continuation at the height $2 Z_{0}$. Thus, the upward continuation at the height $Z_{0}$ eliminates the effect of the sources situated above the depth $\frac{Z_{0}}{2}$.

\subsection{Method of Source-Depth Estimation Using Spectral Analysis}

The spectral analysis is an interpretation technique based on the study of power 
spectrum properties. This method, applying on profiles as well as on data grids, was carried out through 2-D Fast Fourier Transform (FFT), to estimate depths for the major structures which cause the measured anomaly.

According to this method, as described by [45], the depth of a perturbing body source is obtained from the negative slope of the linear relationship between the logarithmic power spectrum and the wave number of the gravity field. This method is well established and proved its usefulness in schemes of interpretation in gravity [35] [46] [47] [48].

\subsection{5D Forward Modelling}

The 2.5D gravity modelling was carried out using the interactive computer program GRAV2DC [49] based on the Talwani algorithm, to calculate the anomaly due to various subsurface structures along a profile [50] [51]. This program requires the strike length, investigation depth, density contrasts and a number of points along a profile. In the program, a calculated anomaly is constructed as generated by a model of subsurface represented by polygons. The best model is obtained when the theoretical anomaly matches closely the observed data. In order to constrain the gravity modeling process, all the available independent information have been taken into account, namely the geological knowledge, results of spectral analysis and previous estimation of investigation depth.

\section{Results}

\subsection{Analysis of Bouguer Anomaly}

The Bouguer gravity anomaly map of the study area displays negative value from -48 to $-110 \mathrm{mGal}$ (Figure 3 ).

The relatively positive and negative anomalies are symmetrically opposed, with respect to NE-SW direction that constitutes the transition zone. The relatively negative anomalies ( -80 to $-110 \mathrm{mGal}$ ) cover the localities of Mbouda and Fokoue with the minima $(-110 \mathrm{mGal})$ centered at the extreme $\mathrm{NW}$ of the area. This feature could be related to the caldera of Mt Bambouto which is made up of low density felsic lavas such as trachyte, ignimbrite and phonolite [52]. The relatively positive anomalies $(-68$ to $-50 \mathrm{mGal})$ are restricted in the extreme SE and SW of the study area. These values are probably due to Precambrian high grade gneiss outcropping at the SE and the association of norite and Precambrian-high grade gneiss in the area of Kekem, respectively. Both areas mentioned above are separated by a NE-SW striking corridor which is delineated in its northern border by NE-SW highly tight anomaly gradient in the area of Bafoussam. This gradient may be the geophysical signature of the $\mathrm{N} 40-50^{\circ} \mathrm{E}$ branch of the Pan-African Central Cameroon Shear Zone in the area. Contrarily, in its southern border, an arc shaped iso-anomal counter, matches the geometry of Bazou granitic massif. In addition, negative anomalies are observed at Bangou with nearly circular shaped contours. This is probably due to the intrusion of Bangou granitic massif. 


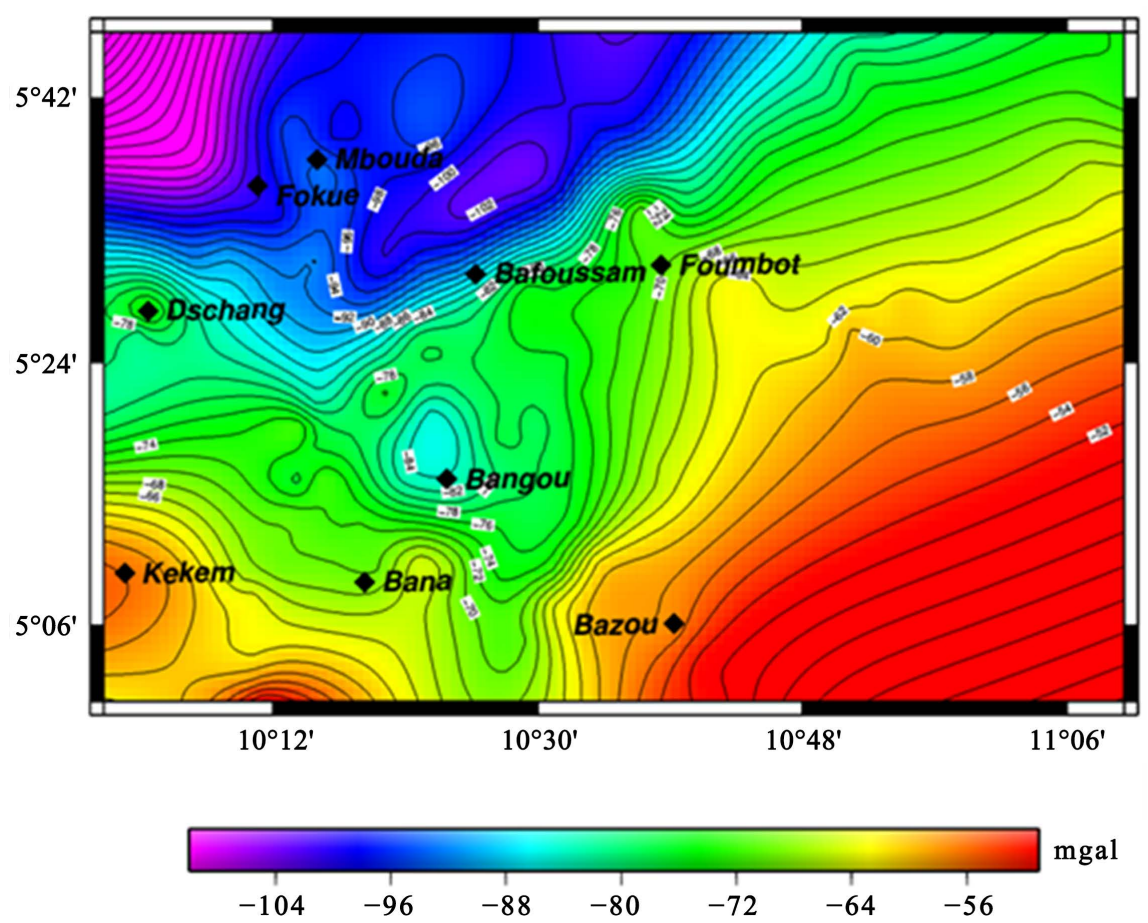

Figure 3. Bouguergravity anomaly map of the study area (intervals: $2 \mathrm{mGals}$; color-scale unit: $\mathrm{mGal}$; projection: Mercator).

\subsection{Estimation of the Optimum Upward-Continuation Height for Gravity Separation and Investigation Depth}

In order to derive an optimum upward continuation height $\mathrm{H}_{0}$ for regional-residual gravity separation, the correlation factor is plotted as a function of increasing continuation height (Figure 4(a)). This is done in such a way that, each correlation factor corresponds to the lower of the two successive heights. The deflection (denoted C on Figure 4(a)) at each height is given by the gap between the correlation factor curve and the line joining the two ends of the curve.

The curve showing the deflection at each height (Figure 4(b)) attains a maximum at the height $\mathrm{H}_{\mathrm{o}}=35 \mathrm{~km}$, corresponding to the optimum upward continuation height.

To choose the order of the regional field which fixes the residual one, we calculate the coefficients of correlation between the upward continued Bouguer field at $\mathrm{H}_{0}=35 \mathrm{~km}$ and the regional anomaly field for various orders. We have used the Fourpot program to calculate the upward continuation [53]. The results are presented in the graph of Figure 4(c). It is noted that the upward continued Bouguer field at optimum height has a maximum correlation with the regional anomaly field of order 1 . The correlation coefficient factor which imposes the polynomial order selection is very high and equals to 0.99119 . This polynomial degree is particular interesting as we have a better chance of locating the roof of intrusive igneous rocks situated in the upper crust.

As far as the investigation depth in this region is concerned, it is situated at 


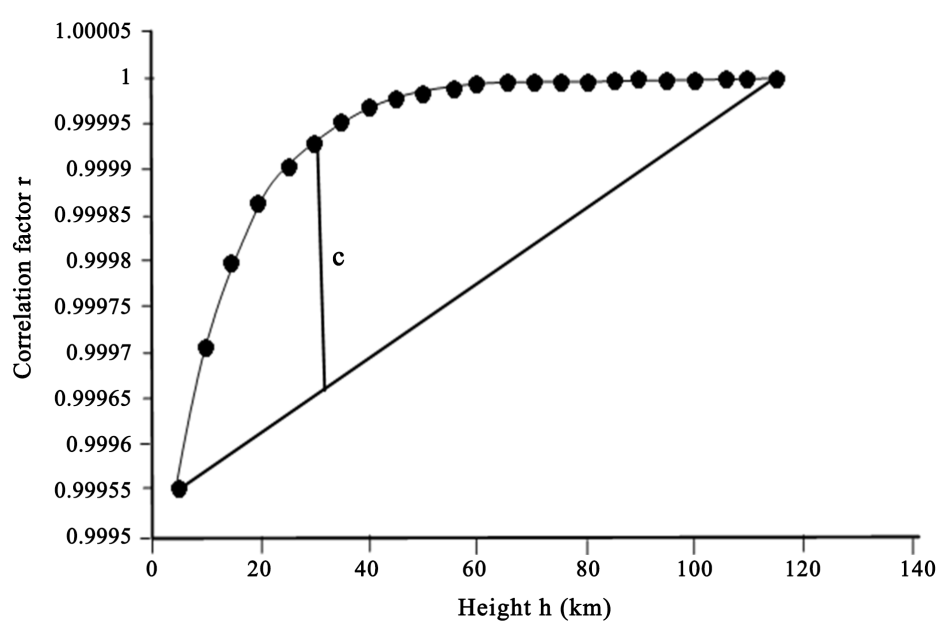

(a)

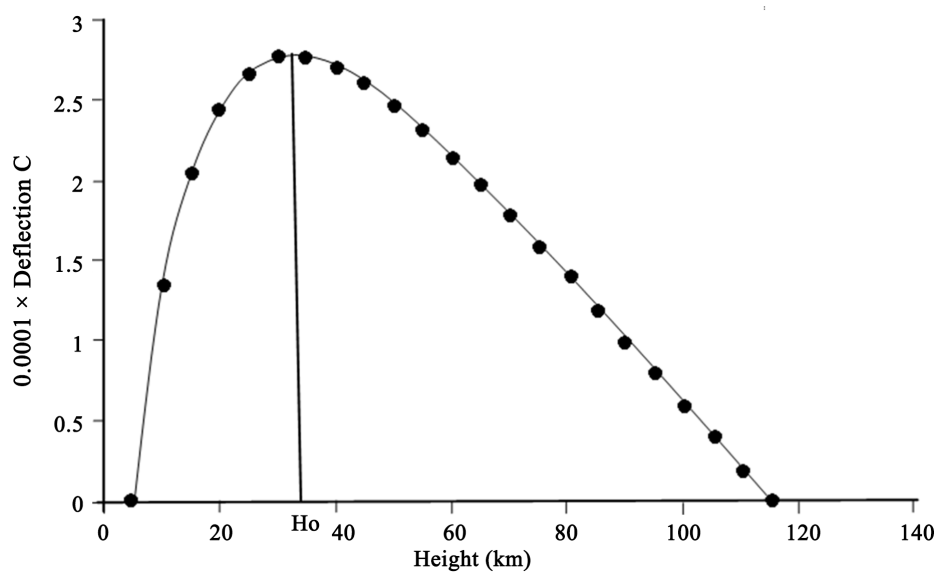

(b)

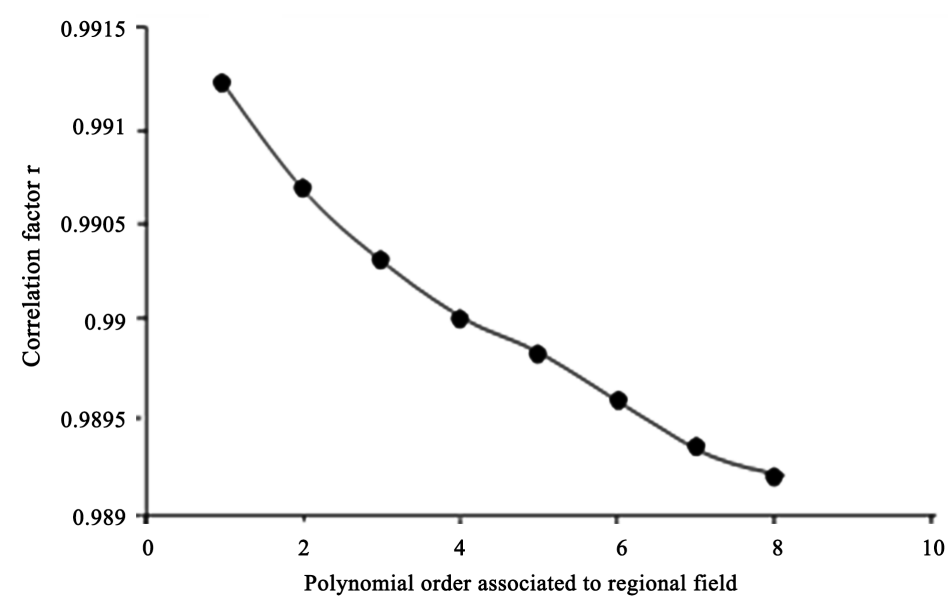

(c)

Figure 4. (a) Cross-correlation between two successive upward continuated gravity field as a function of the continuation height; $\mathrm{C}$ is the deflection; (b) Deflection $\mathrm{C}$ as a function of the continuation height. $\mathrm{H}_{0}$ is optimum upward continuation height; (c) Cross-correlation between upward continuated gravity field at $\mathrm{H}_{0}=35 \mathrm{~km}$ and regional gravity anomaly as function of the polynomial order associated to the regional gravity field (c). 
the height $\mathrm{h}=17.5 \mathrm{~km}$ (Section 3.3: Estimation method of the investigation depth). Consequently, the residual gravity anomaly in the region will highlight essentially the structures which do not exceed the height $\mathrm{h}=17.5 \mathrm{~km}$.

The curve showing the deflection at each height (Figure 4(b)) attains a maximum at the height $\mathrm{H}_{\mathrm{o}}=35 \mathrm{~km}$, corresponding to the optimum upward continuation height.

To choose the order of the regional field which fixes the residual one, we calculate the coefficients of correlation between the upward continued Bouguer field at $\mathrm{H}_{0}=35 \mathrm{~km}$ and the regional anomaly field for various orders. We have used the Fourpot program to calculate the upward continuation [53]. The results are presented in the graph of Figure 4(c). It is noted that the upward continued Bouguer field at optimum height has a maximum correlation with the regional anomaly field of order 1 . The correlation coefficient factor which imposes the polynomial order selection is very high and equals to 0.99119 . This polynomial degree is particular interesting as we have a better chance of locating the roof of intrusive igneous rocks situated in the upper crust.

\subsection{Analysis of Residual Gravity Anomaly}

The first order residual anomaly map (Figure 5 ) shows relatively positive anomaly ranging from -16 to $28 \mathrm{mGal}$ with sub-circular shapes whose maxima are located in the localities of Dschang, Kekem and around Foumbot.

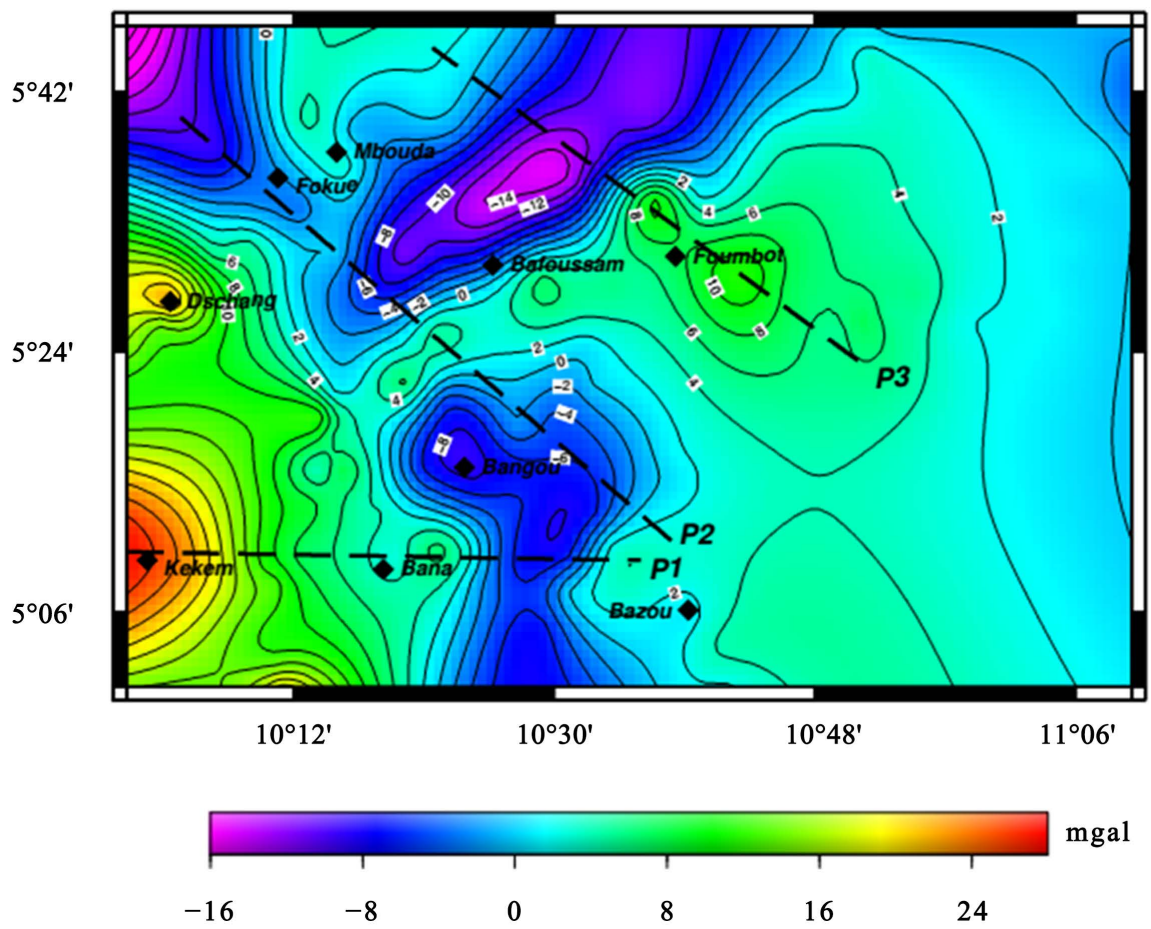

Figure 5. Residual anomaly map of the study area (Contour interval: 2 mGals; color-scale unit: $\mathrm{mGal}$; projection: Mercator). Black squares represent locations of some towns in the studied area and the dashed lines represent the profiles used for the gravity models shown on Figure 8. 
These maxima are likely related to the intrusion of mafic dense rocks. Three low gravity anomaly domains are observed on the map. The first area with minima values were observed at the extreme NW of the map, where the contours are slightly elongated towards the SE. This could be related to the emplacement of Babadjou volcanic plug associated to low density materials such as trachytes, rhyolites and phonolites that form the caldera.

The second area $(-14 \mathrm{mGal})$ is sandwiched between Mbouda and Bafoussam with NE-SW oriented iso-anomal contours, are bordered by high gradient anomaly. These gradients are the signature of the SW prolongation of the $\mathrm{N} 40-50^{\circ} \mathrm{E}$ branch of the Pan-African Central Cameroon Shear Zone in the Area [54]. The low anomaly observed may be due to the emplacement of the sheet-like granitoids reported in the area [22] [25] and volcanic low density products (pyroclastic materials) emitted through the Baleng Lake exposed in the area. The third low gravity anomaly area in Bangou, displays a NW-SE oriented which then curves into $\mathrm{N} 20^{\circ} \mathrm{E}$ and comes back to the NW-SE trend. This feature is probably related to post-tectonic emplacement of low density materials (Bangou granite).

\subsection{Spectral Analysis Results}

In order to determine the depth of the major density discontinuities in the upper crust, three plots of the logarithm function of the average power spectrum versus the wave number for the gravity residual anomaly were derived (Figure 6). The high wave number position is due to the shallow bodies while the deep seated bodies cause the low wave number. From the deepest to the shallowest, three depths assumed to correlate with the upper crustal density discontinuities have been interpreted.

The mean depth estimates for the deepest discontinuity in the upper crust, along the NW-SE oriented P2 gravity residual profile is $\mathrm{H} 1=18 \pm 1 \mathrm{~km}$.

The depth $\mathrm{H} 1=18 \pm 1 \mathrm{~km}$ may probably correspond to an interface between the upper and the lower crust in the region. This result ties very closely with the investigation depth of $17.5 \mathrm{~km}$, determined through the upward continuation method and is consistent with that mentioned by [9].

Along the profile P3 crossing the Mbapit Massif, the depth of $14 \pm 1 \mathrm{~km}$ may probably indicate the ascent of the volcanic rocks. This result is consistent with that obtained by [9], interpreted to be related to the Cameroon Volcanic Line (CVL). Depth estimates of $10.5 \pm 0.5 \mathrm{~km}, 10.3 \pm 0.5 \mathrm{~km}$ respectively for NW-SE oriented P2 profile and E-W oriented P1 profile may also explain the uplift of the volcanic materials along those profiles. Moreover, the depth $\mathrm{H}=3.2 \pm 0.2$ $\mathrm{km}$ shallowest one, obtained along the NW-SE oriented P2 and P3 profiles, may be associated to the recovery depth of the trachyte in the Mbouda area while those for P3 profile, crossing the Mbapit Massif may correspond to the base of rhyolitic tuff observed around this massif. Again, we observed that this ascent is very important around the Bana Complex, Mbapit Massif, and volcanic plug of Babadjou and in the FongoTongo area. All those areas are dominated by the 

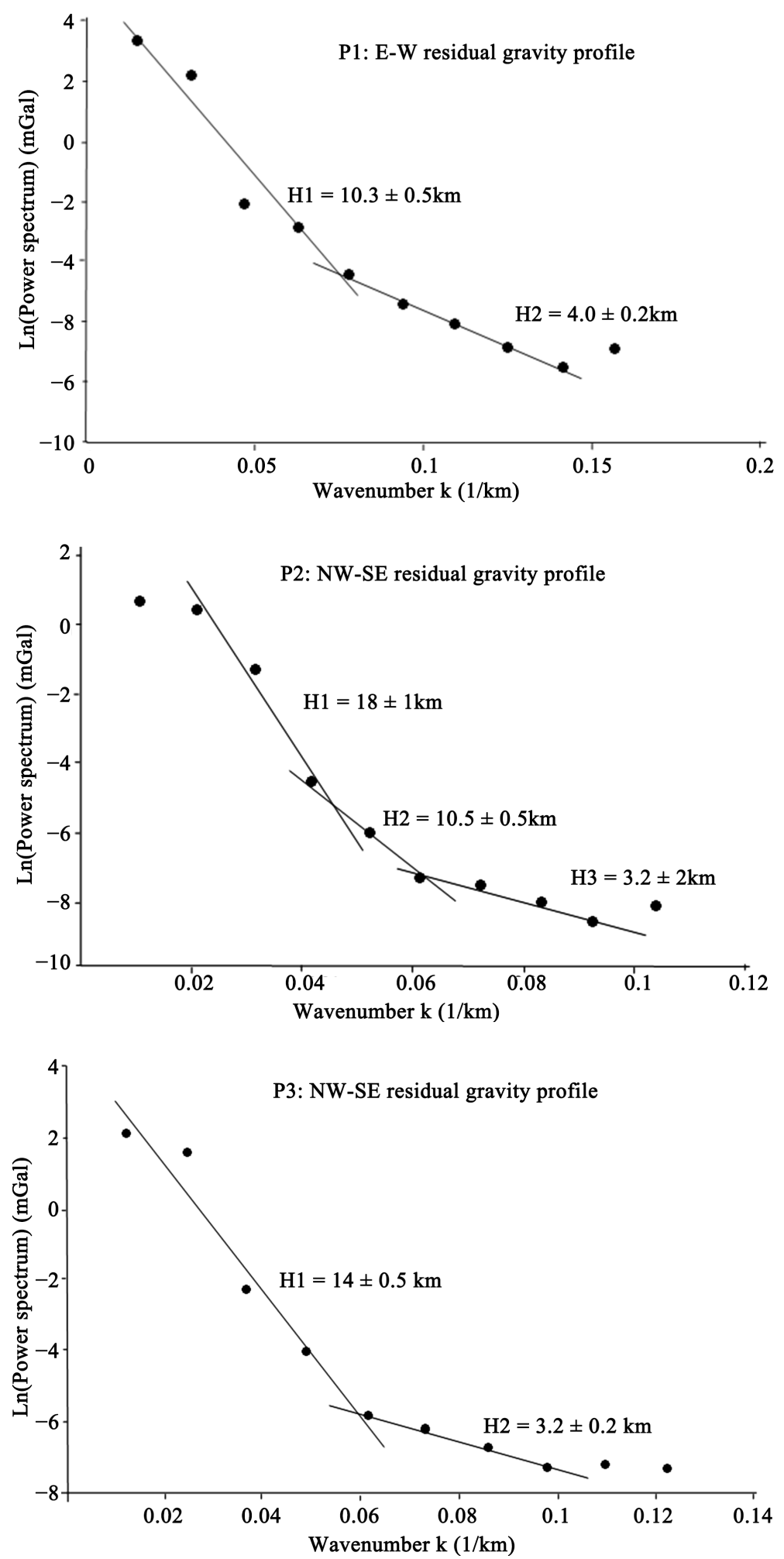

Figure 6. Power spectral analysis of gravity data. Plots of logarithm averaged power spectrum of the residual gravity anomaly over the West area versus the wavenumber (frequency) for profiles P1 oriented along E-W and P2 and P3 oriented along NW-SE. H1: deep density contrast plane corresponding to high wavenumber; $\mathrm{H} 2$ : shallow density contrast plane low wavenumber are estimated from the negative slope of the corresponding segments. 
Cenozoic to Tertiary volcanic rocks. The depth estimate of $4.0 \pm 0.2 \mathrm{~km}$ along $\mathrm{E}-\mathrm{W}$ oriented P1 profile may be ascribed to the emplacement of norite in the area of Kekem.

\subsection{5D Gravity Forward Results}

For a more detail study of the structure of the upper crust and to have a proper understanding of the emplacement of mafic body into the upper crust in the area, three profiles are selected. To constrain the gravity models, all the available independent information (geological knowledge, results of spectral analysis, previous estimation of investigation depth) have been taken into account. The density contrasts used in this section are determined from the density values published in [6] [55], which vary in the following ranges (in $\mathrm{g} \cdot \mathrm{cm}^{-3}$ ): $2.50-2.81$ for granite; 2.50 - 2.80 for trachyte; 2.35 - 2.70 for rhyolite; 2.59 - 3.0 for gneiss; 2.4 3.1 for migmatites; $2.70-3.30$ for basalts. The density contrasts are calculated relative to gneiss which is considered as the host rock. In all of the model profiles, the observed residual anomaly is plotted as black solid dots and the gravity response of the model is a thin black curve.

The E-W P1 profile (Figure 7) shows a high anomaly, decreasing towards the west and displays a graben-horst like outline with steep slopes.

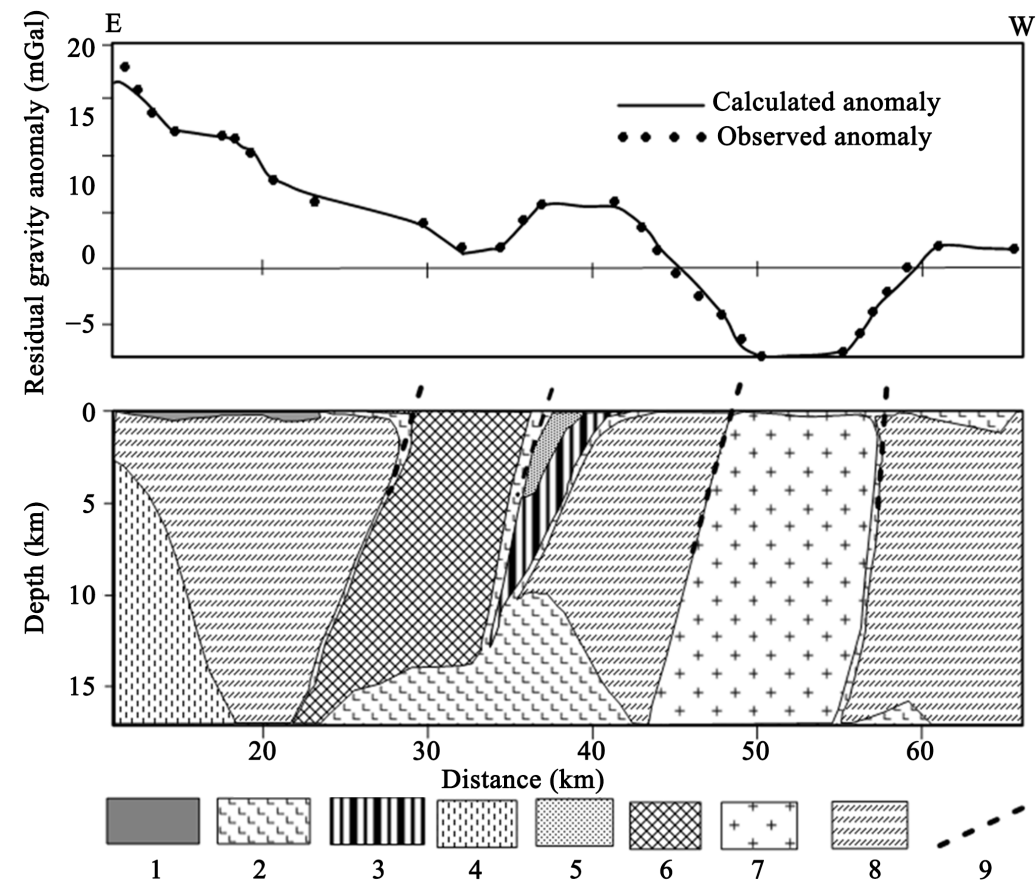

Figure 7. 2.5D residual gravity model of E-WP1 profile of Figure 5. The upper panel shows calculated and observed residual gravity anomaly and lower section shows the adopted model distributions. Black dots show observed anomaly and solid curve shows calculated anomaly. 1: Alluvial deposit $\rho=2.4 \mathrm{~g} \cdot \mathrm{cm}^{-3} 2$ : Mafic body $\rho=2.85 \mathrm{~g} \cdot \mathrm{cm}^{-3}$; 3 : Anorogenic complex of Bana: $\rho=2.65 \mathrm{~g} \cdot \mathrm{cm}^{-3}$; 4 : Norite $\rho=2.92 \mathrm{~g} \cdot \mathrm{cm}^{-3}$; 5: Trachyte $\rho=2.6 \mathrm{~g} \cdot \mathrm{cm}^{-3} ; 6$ : Syntectonic granite (deliminated) $\rho$ $=2.65 \mathrm{~g} \cdot \mathrm{cm}^{-3} ; 7$ : Syntectonic granite (undeliminated) $\rho=2.65 \mathrm{~g} \cdot \mathrm{cm}^{-3} ; 8$ : Gneiss $\rho$ $=2.7 \mathrm{~g} \cdot \mathrm{cm}^{-3} ;$ 9: Proposed fault. 
The high anomaly is likely due to the ascension of dense basic rocks; probably norite with density of $\rho=2.92 \mathrm{~g} \cdot \mathrm{cm}^{-3}$, whose roof is emplaced at depth of about $3.8 \mathrm{~km}$ outcropping at Kekem. The horst-shaped section of the profile is related to the upwelling of the mafic body whose roof is located at a depth of about 10 $\mathrm{km}$. This is consistent with the spectral analysis results which reveal contrast density at $10 \mathrm{~km}$ of depth. At the end of the profile, the large graben like shape is related to the emplacement of a dipping $14 \mathrm{~km}$ width tabular Bazou granite.

The NW-SE oriented P2 profile displays a successive graben and horst-like curve (Figure 8). This feature is likely due to multiple intrusion of granite sheet of various dimensions in the area.

The graben-like curve corresponds to Fomopéa, Batié and Bazou granites with density of $\rho=2.65 \mathrm{~g} \cdot \mathrm{cm}^{-3}$, respectively from NW to SE along the profile.

However, the upwelling of the dense basic materials with density of $\rho=2.85$ $\mathrm{g} \cdot \mathrm{cm}^{-3}$ whose roof is located between $13.5 \mathrm{~km}$ and $16.5 \mathrm{~km}$ can be observed. The steep gradient which separates the graben and horst-like shape of gravity anomaly may correspond to the granite gneiss discontinuity. The latter are interpreted to be a weakness zone which constitutes the pathway for magma ascent. This shear zone coincides with the N40-50 ${ }^{\circ}$ branch of CCSZ [21] [22] [23].

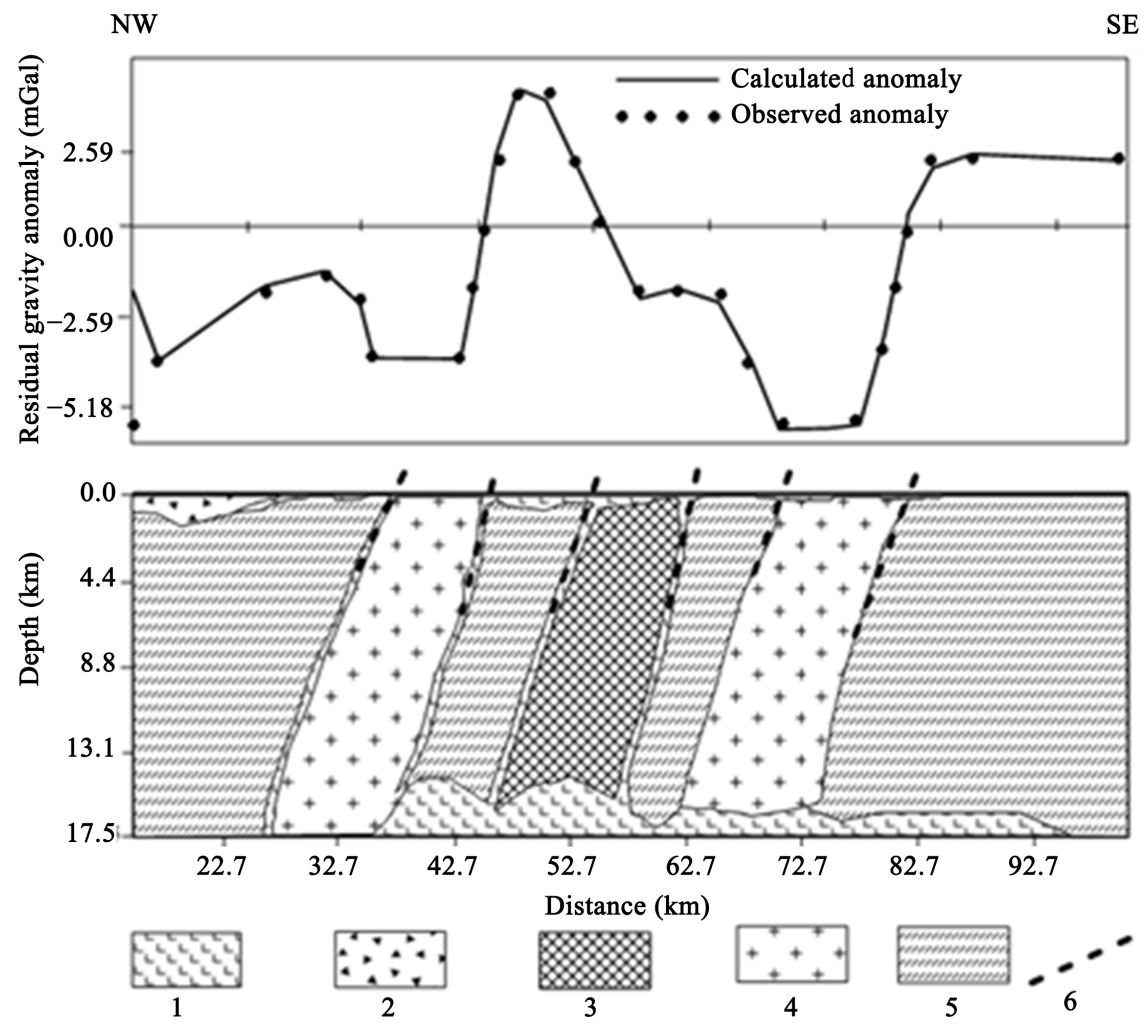

Figure 8. 2.5D residual gravity model of NW-SEP2 profile of Figure 5. The upper panel shows calculated and observed residual gravity anomaly and lower section shows the adopted model distributions. Black dots show observed anomaly and solid curve shows calculated anomaly. 1: Mafic body $\rho=2.85 \mathrm{~g} \cdot \mathrm{cm}^{-3} ; 2$ : Trachyte $\rho=2.6 \mathrm{~g} \cdot \mathrm{cm}^{-3} ; 3$ : Syntectonic granite (deliminated) $\rho=2.65 \mathrm{~g} \cdot \mathrm{cm}^{-3}$; 4: Syntectonic granite (undeliminated) $\rho=$ $2.65 \mathrm{~g} \cdot \mathrm{cm}^{-3}$; 5: Gneiss $\rho=2.7 \mathrm{~g} \cdot \mathrm{cm}^{-3} ; 6$ : Proposed fault. 
At the beginning of the NW-SE oriented P3 profile (Figure 9), the low gravity anomaly with amplitude not greater than $4 \mathrm{mGal}$ are observed. This anomaly may be associated to the internal influence of large granitic rocks occurring in the area.

The high but increasing anomaly value following the latter observed, is likely due to the intrusion of the basic mafic rocks whose roof is located at $3.2 \mathrm{~km}$ under the Mbapit Massif. This uppermost ascension could be explained by the intense volcanic activity occurring in the area. The steep gradient of the gravity anomaly observed in the area may correspond to a lateral granite-gneiss discontinuity. The progressive lateral discontinuities constitute the pathway for magmatic materials to reach to earth's surface.

\section{Discussion}

\subsection{Intrusion of the Mafic Bodies beneath the $\mathrm{N40-50}{ }^{\circ} \mathrm{E}$ Striking Shear Zone}

The Bouguer and residual gravity anomaly maps reveal a $\mathrm{N} 40-50^{\circ} \mathrm{E}$-directed highly tight gradient anomaly in the Bafoussam area. Tight gradient anomaly is commonly interpreted as fault [6] [48]. Therefore, the same interpretation can be
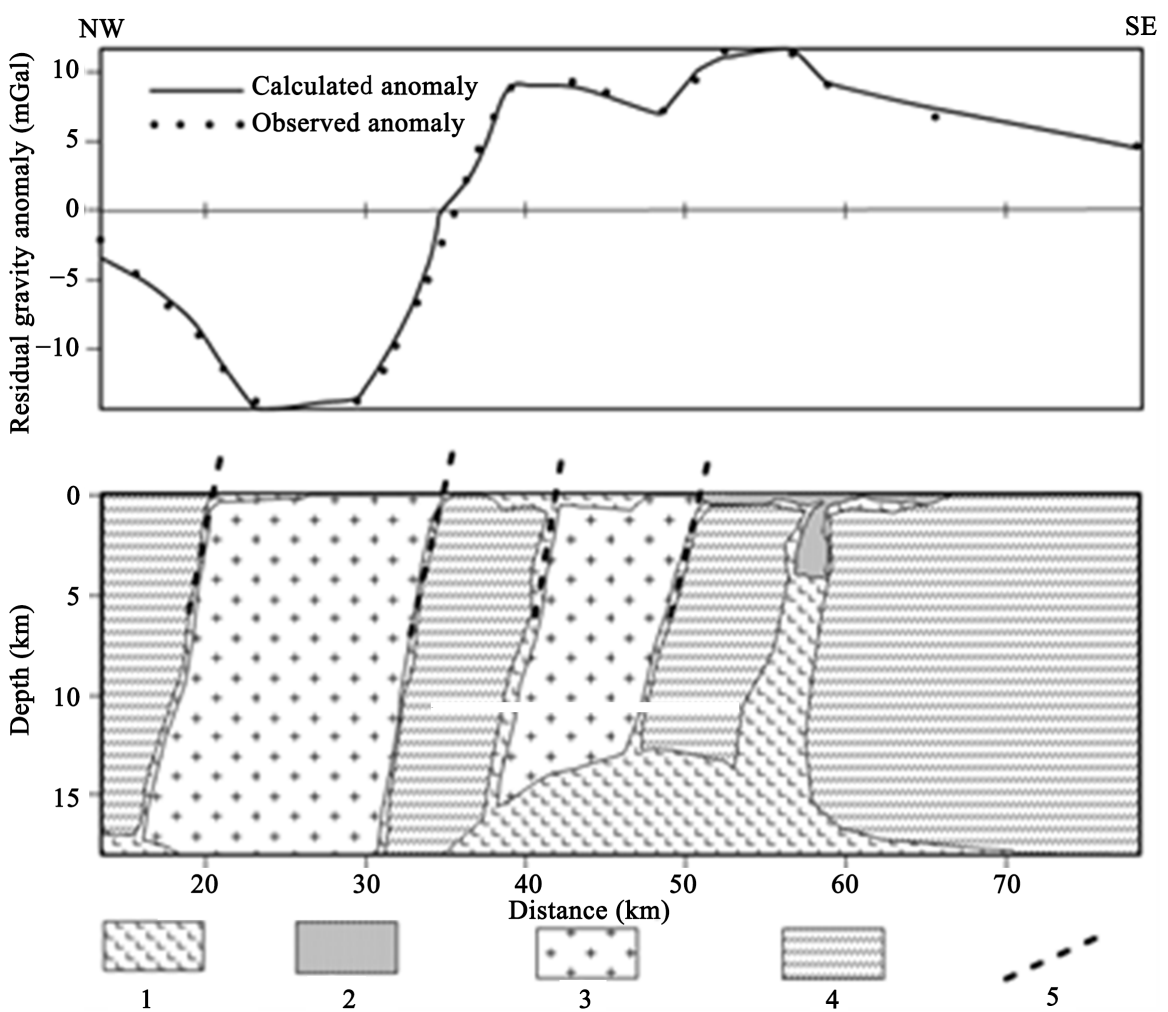

Figure 9. 2.5D residual gravity model of NW-SEP3 profile of Figure 5. The upper panel shows calculated and observed residual gravity anomaly and lower section shows the adopted model distributions. Black dots show observed anomaly and solid curve shows calculated anomaly. 1: Mafic body $\rho=2.85 \mathrm{~g} \cdot \mathrm{cm}^{-3} ; 2$ : Rhyolitic tuff $\rho=2.53 \mathrm{~g} \cdot \mathrm{cm}^{-3} ; 3$ : Syntectonic granite (undeliminated) $\rho=2.65 \mathrm{~g} \cdot \mathrm{cm}^{-3} ; 4$ : Gneiss $\rho=2.7 \mathrm{~g} \cdot \mathrm{cm}^{-3}$; 5 : Proposed fault. 
envisaged for the Bafoussam area. Further, this feature is consistent with the sub-vertical $\mathrm{N} 40^{\circ}-50^{\circ} \mathrm{E}$ striking mylonitic band known as the $\mathrm{N} 40-50^{\circ} \mathrm{E}$ branch of the Cameroon Central Shear Zone [20] [21] [22] [23]. Moreover, 2.5D gravity modeling shows that the mafic denser bodies are elongated under the $\mathrm{N} 40-50^{\circ} \mathrm{E}$ strike lineament which corresponds to the Foumban-Foutoni shear zone [23] and also indicates that magma ascent into the surface is closely associated with that shear zone. In addition, the spectral analysis and 2.5D gravity modeling reveal the emplacement of mafic denser body at depth comprised between 3 and $14 \mathrm{~km}$ with the highest roof of mafic intrusion under volcanic centers (e.g. $3.2 \pm$ $0.2 \mathrm{~km}$ under Mt Bamboubo and Mt Mbapit volcanic massifs). These NE aligned volcanic centers under which the highest roofs are observed matches well with the NE striking CCSZ, which suggest a possible relation between the shear zone and the emplacement of the mafic bodies. Similarly, denser mafic bodies were also reported beneath the Adamawa from gravity studies [6] [9] [11], which constitutes the $\mathrm{N} 60-70^{\circ} \mathrm{E}$ branch of the CCSZ. Beneath the N60-N70 ${ }^{\circ}$-directed strike slip shear zone known as the Adamawa Shear Zone (ASZ) which has been proven to result from transcurrent tectonic [20] [55], are closely run by dense materials at depths varying between 5 and $10 \mathrm{~km}$. This is interpreted as an igneous intrusion probably of basaltic composition emplaced in relation to the magmatic activities in the area [6] [9] [11]. The close relationship between the Adamawa Shear Zone and the magma ascent into the surface or the intrusion of mafic materials into the upper crust, suggested that their emplacement was facilitated by the reactivation of the Adamawa Shear Zone [6] [7]. However, there is no consensus from the interpretation from seismic studies. A low velocity zone at $10 \mathrm{~km}$ with $\mathrm{Vp} / \mathrm{Vs}$ bracketed between 1.88 and 1.6 was revealed by [5]. This intermediate value are probably originated from low mafic intrusions restricted under CVL as evidence gravity studies [6] [7] [8] [9] [11] and VP speed recorded in many seismic stations [5]. However, the low velocity comprised between 1.6 and 1.88 characterizes granitic and mafic materials respectively. This intermediate value is likely related to the upwelling of the denser mafic body as seismic stations are away from volcanic centers (more than $65 \mathrm{~km}$ ) under which the magma upwelling is recorded.

\subsection{Mechanism of the Mafic Body Intrusion in the Upper Crust}

The study area is part of the central domain of the Pan-African fold belt, which is characterized by a network of Pan-African transcurrent/transpressional shear zone. It strikes $\mathrm{N} 60-\mathrm{N} 70^{\circ} \mathrm{E}$ in the area of the Adamawa region [6] [11] [20] [34] [55] [56] which turn into $\mathrm{N} 40^{\circ} \mathrm{E}$ in the Foumban-Fotouni area [20] [21] [22] [23]. This feature is a part of the central Africa shear zone which runs to Dafur in Sudan and presumed to trace into Pernambuco in north east Brazil. Gravity studies carried out either in the $\mathrm{N} 70^{\circ} \mathrm{E}$ striking shear zone in the area of Adamawa [6] [7] [11] or in the $\mathrm{N} 40-50^{\circ} \mathrm{E}$ in west region (this study) reveal the existence of mafic bodies at depth between 3 and $14 \mathrm{~km}$ with the highest roof of the 
mafic intrusion (this study) under the Cenozoic volcanic centers. Furthermore, in CCSZ the lithosphere is thinned following asthenospheric upwelling [11] or basal erosion [1] [2]. As CCSZ is deep-seated lithospheric-scale structure [9] [11] [22], it might have served as pathways for magma upwelling and crystallization into the upper crust.

\section{Conclusion}

The Bouguer and the residual gravity anomaly maps reveal $\mathrm{N} 40-50^{\circ} \mathrm{E}$ oriented iso-anomal contours associated to negative anomaly, related to low density materials corresponding to sheeted-like granite and felsic lavas (trachyte and rhyolite). This feature corresponds to geophysical signature of $\mathrm{N} 40-50^{\circ} \mathrm{E}$ branch of the Pan-African CCSZ in the west region. Moreover, the spectral analysis and $2.5 \mathrm{D}$ gravity modelling evidence the upwelling of mafic bodies at depth situated between $3.2 \mathrm{~km}$ to $14.2 \mathrm{~km}$ beneath the $\mathrm{N} 40-50^{\circ} \mathrm{E}$ branch of the Pan-African CCSZ. The magma ascent in the upper crust beneath the $\mathrm{N} 40-50^{\circ} \mathrm{E}$ branch is similar to that reported in the Adamawa plateau. The emplacement of these bodies into the upper crust could be related to the interaction between the NE-ward channel flow operating at the bottom of the lithosphere or the asthenosphere upwelling and the deep seated CCSZ. Further geophysical studies from combined more recent ground gravity data and GOCE satellite data will help to constrain the deeper seated features necessary to improve knowledge about the upwelling of mafic bodies beneath the Pan-African Central Cameroon Shear Zone.

\section{Acknowledgements}

We express our gratitude to IRD (Institut de Recherche pour le Développement, France) for providing the gravity data used in this study. We also appreciate the anonymous reviewers for their comments and suggestions which helped them improve the paper.

Avoid the stilted expression, "One of us (R. B. G.) thanks ..." Instead, try "R. B. G. thanks". Do NOT put sponsor acknowledgements in the unnumbered footnote on the first page, but at here.

\section{References}

[1] Adams, A.N., Wiens, D.A., Nyblade, A.A., Euler, G.G., Shore, P.J. and Tibi, R. (2015) Lithospheric Instability and the Source of the Cameroon Volcanic Line: Evidence from Rayleigh Wave Phase Velocity Tomography. Journal of Geophysical Research, 120, 1708-1727. https://doi.org/10.1002/2014JB011580

[2] De Plaen, R.S.M., Bastow, I.D., Chambers, E.L., Keir, D., Gallacher, R.J. and Keane, J. (2014) The Development of Magmatism along the Cameroon Volcanic Line: Evidence from Seismicity and Seismic Anisotropy. Journal of Geophysical Research, 119, 4233-4252. https://doi.org/10.1002/2013JB010583

[3] Elsheikh, A.A., Gao, S.S. and Liu, K.H. (2014) Formation of the Cameroon Volcanic Line by Lithospheric Basal Erosion: Insight from Mantle Seismic Anisotropy. Jour- 
nal of African Earth Sciences, 100, 96-108.

https://doi.org/10.1016/j.jafrearsci.2014.06.011

[4] Gallacher, R.J. and Bastow, I.D. (2012) The Development of Magmatism along the Cameroon Volcanic Line: Evidence from Teleseismic Receiver Functions. Tectonics, 31, TC3018. https://doi.org/10.1029/2011TC003028

[5] Tokam, K.A.P., Tabod, C.T., Nyblade, A.A., Julia, J., Wiens, D.A. and Pasyanos, M. (2010) Structure of the Crust beneath Cameroon, West Africa, from the Joint Inversion of Rayleigh Wave Group Velocities and Receiver Functions. Geophysical Journal International, 183, 1061-1076. https://doi.org/10.1111/j.1365-246X.2010.04776.x

[6] Noutchogwe, T.C., Tabod, C.T. and Manguelle-Dicoum, E. (2006) A Gravity Study of the Crust beneath the Adamawa Fault Zone, West Central Africa. Journal of Geophysics and Engineering, 3, 82-89. https://doi.org/10.1088/1742-2132/3/1/009

[7] Noutchogwe, T.C., Koumetio, F. and Manguelle-Dicoum, E. (2010) Structural Features of South-Adamawa (Cameroon) Inferred from Magnetic Anomalies: Hydrogeological Implications C.R. Geoscience, 342, 467-474.

https://doi.org/10.1016/j.crte.2010.03.004

[8] Jean, M., Abate, E.J.M., Nouck, P.N., Ngatchou, H.E., Oyoa, V., Tabod, C.T. and Manguelle-Dicoum, E. (2016) Structure of the Crust beneath the South Western Cameroon, from Gravity Data Analysis. International Journal of Geosciences, 7, 991-1008. https://doi.org/10.4236/ijg.2016.78075

[9] Nnange, J.M., Ngako, V., Fairhead, J.D. and Ebinger, C.J. (2000) Depths to Density Discontinuities beneath the Adamawa Plateau Region, Central Africa, from Spectral Analysis of New and Existing Gravity Data. Journal of African Earth Sciences, 30, 887-901. https://doi.org/10.1016/S0899-5362(00)00058-0

[10] Poudjom-Djomani, Y.H., Diament, M. and Albouy, Y. (1992) Mechanical Behaviour of the Lithosphere beneath the Adamaoua Uplift (Cameroon, West Africa) Based on Gravity Data. Journal of African Earth Sciences, 15, 81-90. https://doi.org/10.1016/0899-5362(92)90009-2

[11] Poudjom-Djomani, Y.H., Diamant, M. and Wilson, M. (1997) Lithospheric Structure across the Adamawa Plateau (Cameroon) from Gravity Studies. Tectonophysics, 273, 317-327. https://doi.org/10.1016/S0040-1951(96)00280-6

[12] Toteu, S.F., Van Schmus, W.R., Penaye, J. and Michard, A. (2001) New U-Pb and Sm-Nd Data from North-Central Cameroon and Its Bearing on the Pre-Pan African History of Central Africa. Precambrian Research, 108, 45-73. https://doi.org/10.1016/S0301-9268(00)00149-2

[13] Deruelle, B., Ngounouno, I. and Demaiffe, D. (2007) The Cameroon Hot Line (CHL): A Unique Example of Active Alkaline Intraplate Structure in Both Oceanic and Continental Lithospheres. Comptes Rendus Geoscience, 339, 589-600. https://doi.org/10.1016/j.crte.2007.07.007

[14] Suh, C., Sparks, R., Fitton, J., Ayonghe, S., Annen, C., Nana, R. and Luckman, A. (2003) The 1999 and 2000 Eruptions of Mount Cameroon: Eruption Behaviour and Petrochemistry of Lava. Bulletin of Volcanology, 65, 267-281. https://doi.org/10.1007/s00445-002-0257-7

[15] Fairhead, J.D. and Binks, R.M. (1991) Differential Opening of the Central and South-Atlantic Oceans and the Opening of the West African Rift System. Tectonophysics, 187, 191-203. https://doi.org/10.1016/0040-1951(91)90419-S

[16] TankoNjiosseu, E.L., Nzenti, J.P., Njanko, T., Kapajika, B. and Nédélec, A. (2005) New U-Pb Zircon Ages from Tonga (Cameroon): Coexisting Eburnean Transama- 
zonian $(2.1 \mathrm{Ga})$ and Pan-African (0.6 Ga) Imprints. Comptes Rendus Geoscience, 337, 551-562. https://doi.org/10.1016/j.crte.2005.02.005

[17] Tchakounté, J.N., Toteu, S.F., Van Schmus, W.R., Penaye, J., MvondoOndoua, J., Deloule, E., BouyoHouketchang, M., Ganwa, A.A. and White, W.M. (2007) Evidence of CA 1.6 Ga Detrital Zircon in the Bafia Group (Cameroon): Implication for the Chronostratigraphy of the Pan-African Belt North of the Congo Craton. Comptes Rendus Geoscience, 339, 132-142.

https://doi.org/10.1016/j.crte.2007.01.004

[18] Toteu, S.F., Penaye, J. and Poudjom-Djomani, Y. (2004) Geodynamic Evolution of the Pan-African Belt in Central Africa with Special Reference to Cameroon. Canadian Journal of Earth Sciences, 41, 73-85. https://doi.org/10.1139/e03-079

[19] TchaptchetTchato, D., Schulz, B. and Nzenti, J.P. (2009) Electron Microprobe Dating and Thermobarometry of Neoproterozoic Metamorphic Events in the Kekem Area, Central African Fold Belt of Cameroon. Neues Jahrbuch für Mineralogie Abhandlungen, 186, 95-109. https://doi.org/10.1127/0077-7757/2009/0140

[20] Ngako, V., Affaton, P., Nnange, J.M. and Njanko, T. (2003) Panafrican Tectonic Evolution in Central and Southern Cameroon: Transpression and Transtention during Sinistral Shear Movements. Journal of African Earth Sciences, 36, 207-214. https://doi.org/10.1016/S0899-5362(03)00023-X

[21] Njiekak, G., Dörr, W., Tchouankoue, J.P. and Zulauf, G. (2008) U-Pb Zircon and Microfabric Data of (Meta) Granitoids of Western Cameroon: Constraints on the Timing of Pluton Emplacement and Deformation in the Pan-African Belt of Central Africa. Lithos, 102, 460-477. https://doi.org/10.1016/j.lithos.2007.07.020

[22] Njonfang, E., Ngako, V., Moreau, C., Affaton, P. and Diot, H. (2008) Restraining Bends in High Temperature Shear Zone: The Central Cameroon Shear Zone, Central Africa. Journal of African Earth Sciences, 52, 9-20. https://doi.org/10.1016/j.jafrearsci.2008.03.002

[23] TcheumenakKouémo, J., Njanko, T., Kwékam, M., Naba, S., Bella Nké, B.E., YakeuSandjo, A.F., Fozing, E.M. and Njonfang, E. (2014) Kinematic Evolution of the Fodjomekwet-Fotouni Shear Zone (West-Cameroon): Implications for Emplacement of the Fomopéa and Bandja Plutons. Journal of African Earth Sciences, 99, 261-275. https://doi.org/10.1016/j.jafrearsci.2014.07.018

[24] Djouka-Fonkwé, M.L., Schulz, B., Schüssler, U., Tchouankoué, J.P. and Nzolang, C. (2008) Geochemistry of the Bafoussam Pan-African I- and S-Type Granitoids in Western Cameroon. Journal of African Earth Sciences, 50, 148-167. https://doi.org/10.1016/j.jafrearsci.2007.09.015

[25] KouankapNono, G.D., Nzenti, J.P., Suh, C.E. and Ganno, S. (2010) Geochemistry of Ferriferous, High-K Calc-Alkaline Granitoids from the Banefo-Mvoutsaha Massif (NE Bafoussam), Central Domain of the PanAfrican Fold Belt, Cameroon. The Open Geology Journal, 4, 15-28. https://doi.org/10.2174/1874262901004010015

[26] Dumort, J.C. (1968) Notice explicative de la carte géologique de reconnaissance du Cameroun au 1/500 000. Feuille Douala Ouest. Direction des Mines et Géologie du Cameroun. Earth Science, 13, 549-559.

[27] Tchouankoue, J.P., SimeniWambo, N.A., KagouDongmo, A. and Wörner, G. (2012) Petrology, Geochemistry, and Geodynamic Implications of Basaltic Dyke Swarms from the Southern Continental Part of the Cameroon Volcanic Line, Central Africa. Open Geology Journal, 6, 72-84. https://doi.org/10.2174/1874262901206010072

[28] Tchouankoue, J.P., SimeniWambo, N.A., KagouDongmo, A. and Li, X.H. (2014) 
40Ar/39Ar Dating of Basaltic Dykes Swarm in Western Cameroon: Evidence of Late Paleozoic and Mesozoic Magmatism in the Corridor of the Cameroon Line. Journal of African Earth Sciences, 93, 14-22. https://doi.org/10.1016/j.jafrearsci.2014.01.006

[29] Wandji, P., TchokonaSeuwi, D., Bardintzeff, J.M., Bellon, H. and Platevoet, B. (2008) Rhyolites of the Mbépit Massif in the Cameroon Volcanic Line: An Early Extrusive Volcanic Episode of Eocene Age. Mineralogy and Petrology, 94, 271-286. https://doi.org/10.1007/s00710-008-0013-6

[30] Kuepouo, G., Tchouankoue, J.P., Nagao, T. and Sato, H. (2006) Transitional Tholeiitic Basalts in the Tertiary Bana Volcanoplutonic Complex, Cameroon Line. Journal of African Earth Sciences, 45, 318-332. https://doi.org/10.1016/j.jafrearsci.2006.03.005

[31] Fosso, J., Ménard, J.J., Bardintzeff, J.M., Wandji, P., Tchoua, F.M. and Bellon, H. (2005) Les laves du mont Bangou: Une première manifestation volcanique éocène à affinité transitionnelle de la Ligne du Cameroun. Comptes Rendus Geoscience, 337, 315-325. https://doi.org/10.1016/j.crte.2004.10.014

[32] TchuimegnieNgongang, N.B., Kamgang, P., Chazot, G., Agranier, A., Bellon, H. and Nonnotte, P. (2015) Age, Geochemical Characteristics and Petrogenesis of Cenozoic Intraplate Alkaline Volcanic Rocks in the Bafang Region, West Cameroon. Journal of African Earth Sciences, 102, 218-232. https://doi.org/10.1016/j.jafrearsci.2014.10.011

[33] Collignon, F. (1968) Gravimétrie de reconnaissance de la République Fédérale du Cameroun. O.R.S.T.O.M., Paris, 35 p.

[34] Nnange, J.M. (1991) The Crustal Structure of the Cameroon Volcanic Line and the FoumbanShear Zone Based on Gravity and Aeromagnetic Data. PhD Thesis, University of Leeds, Leeds, $242 \mathrm{p}$.

[35] Poudjom-Djomani, Y.H., Nnange, J.M., Diament, M., Ebinger, C.J. and Fairhead, J.D. (1995) Effective Elastic Thickness and Crustal Thickness Variation in West Central Africa Inferred from Gravity Data. Journal of Geophysical Research, 100, 22047-22070. https://doi.org/10.1029/95JB01149

[36] Boukeke, D.B. (1994) Structures crustales d'Afrique Centrale déduites des anomalies gravimétriques et magnétiques: Le domaine précambrien de la République Centrafricaine et du Sud Cameroun. PhD Thesis, Univ. Paris XI, Orsay.

[37] Wessel, P. and Smith, W.H.F. (1995) New Version of GMT Released. Transactions of the American Geophysical Union, 72, 445-446.

[38] Azad, M.R., Koneshloo, M., Kamakarrouhani, A. and Aghajani, H. (2015) Comparison of Factorial Kriging Analysis Method and Upward Continuation Filter to Recognize Subsurface Structures-A Case Study: Gravity Datafrom a Hydrocarbon Field in the Southeast Sedimentary Basins of the East Vietnam Sea. Acta Geophysica, 64, 398-416. https://doi.org/10.1515/acgeo-2015-0068

[39] Skeels, D.C. (1967) What Is Residual Gravity? Geophysics, 32, 872-876. https://doi.org/10.1190/1.1439896

[40] Kamguia, J., Manguelle-Dicoum, E., Tabod, C.T. and Tadjou, J.M. (2005) Geological Models Deduced from Gravity Data in the Garoua Basin, Cameroon. Journal of Geophysics and Engineering, 2, 147-152. https://doi.org/10.1088/1742-2132/2/2/009

[41] Zeng, H., Xu, D. and Tan, H. (2007) A Model Study for Estimating Optimum Upward Continuation Height for Gravity Separation with Application to a Bouguer Gravity Anomaly over a Mineral Deposit, Jilin Province, Northeast China. Geophysics, 72, 145-150. https://doi.org/10.1190/1.2719497

[42] Koumetio, F., Njomo, D., Tabod, C.T., Noutchogwe, T.C. and Manguelle-Dicoum, 
E. (2012) Structural Interpretation of Gravity Anomalies from the Kribi-Edea Zone, South Cameroon: A Case Study. Journal of Environmental \& Engineering, 9, 664-673. https://doi.org/10.1088/1742-2132/9/6/664

[43] Guo, L., Meng, X., Chen, Z., Li, S. and Zheng, Y. (2013) Preferential Filtering for Gravity Anomaly Separation. Computers \& Geosciences, 51, 247-254. https://doi.org/10.1016/j.cageo.2012.09.012

[44] Jacobsen, B.H. (1987) A Case for Upward Continuation as a Standard Separation Filter for Potential-Field Maps. Geophysics, 52, 390-398. https://doi.org/10.1190/1.1442378

[45] Spector, A. and Grant, F.S. (1970) Statistical Models for Interpreting Aeromagnetic Data. Geophysics, 35, 293-302. https://doi.org/10.1190/1.1440092

[46] Erbek, E. and Dolmaz, M.N. (2013) Geophysical Researches (Gravity and Magnetic) of the Eratosthenes Seamount in the Eastern Mediterranean Sea. Acta Geophysica, 62, 762-784. https://doi.org/10.2478/s11600-013-0185-2

[47] Saibi, H., Aboud, E. and Ehara, S. (2011) Analysis and Interpretation of Gravity Data from the Aluto-Langano Geothermal Field of Ethiopia. Acta Geophysica, 60, 318-336. https://doi.org/10.2478/s11600-011-0061-x

[48] Tadjou, J.M., Nouayou, R., Kamguia, J., Kande, H.L. and Manguelle-Dicoum, E. (2009) Gravity Analysis of the Boundary between the Congo Craton and the Pan-African Belt of Cameroon. Austrian Journal of Earth Sciences, 102, 71-79.

[49] Cooper, G.R.J. (2003) GRAV2DC for Windows User's Manual (Version 2.10). Geophysics Department, University of the Witwatersrand, Johannesburg.

[50] Talwani, M., Worzel, J.L. and Landisman, M. (1959) Rapid Gravity Computations for Two-Dimensional Bodies with Application to the Mendicino Submarine Fracture Zone. Journal of Geophysical Research, 64, 49-59. https://doi.org/10.1029/JZ064i001p00049

[51] Pamukçu, O., Gönenç, T., Uyanik, O., Sözbilir, H. and Çakmak, O. (2014) A Microgravity Model for the City of İzmir (Western Anatolia) and Its Tectonic Implementations. Acta Geophysica, 62, 849-871. https://doi.org/10.2478/s11600-014-0203-z

[52] KagouDongmo, A., Nkouathio, D., Pouclet, A., Bardintzeff, J.M., Wandji, P., Nono, A. and Guillou, H. (2010) The Discovery of Late Quaternary Basalt on Mount Bamboutos: Implications for Recent Widespread Volcanic Activity in the Southern Cameroon Line. Journal of African Earth Sciences, 57, 96-108. https://doi.org/10.1016/j.jafrearsci.2009.07.015

[53] Pirttijärvi, M. (2009) FOURPOT. University of Oulu, Department of Physics, Geophysics, Oulu. https://wiki.oulu.fi/x/0oU7AQ

[54] Noutchogwe, T.C., Tabod, C.T., Koumetio, F. and Manguelle-Dicoum, E. (2011) A Gravity Model Study for Differentiating Vertical and Dipping Geological Contacts with Application to a Bouguer Gravity Anomaly over the Foumban Shear Zone, Cameroon. Geophysica, 47, 43-55.

[55] Njanko, T., Nedélec, A. and Affaton, P. (2006) Synkinematic High-K Calc-Alkaline Plutons Associated to the Pan-African Central Cameroon Shear Zone (West-Tibati Area: Petrology and Geodynamic Significance. Journal of African Earth Sciences, 44, 494-510. https://doi.org/10.1016/j.jafrearsci.2005.11.016

[56] Ngako, V., Affaton, P. and Njonfang, E. (2008) Pan-African Tectonics in Northern Cameroon: Implication for the History of Western Gondwana. Gondwana Research, 14, 509-522. https://doi.org/10.1016/j.gr.2008.02.002 